\title{
FACTORS INFLUENCING POSTPARTUM CONTRACEPTIVE UTILIZATION AT THE SITI FATIMAH MOTHER AND CHILD HOSPITAL MAKASSAR
}

\author{
Ghaisani Humairah ${ }^{1}$, Elizabet Catherine Jusuf ${ }^{2}$ \\ ${ }^{1}$ Medicine Study Program, Faculty of Medicine, Hasanuddin University \\ ${ }^{2}$ Department of Obstetrics and Gynaecology, Faculty of Medicine, Hasanuddin University
}

Correspondence author:

\section{Ghaisani Humairah}

Medicine Study Program, Faculty of Medicine, Hasanuddin University

Email: ghumairah01@gmail.com

\section{Article Info: \\ Received: 2 June 2018 \\ Revised: 25 June 2018 \\ Accepted: 30 June 2018 \\ Available online: 31 December \\ 2018}

Keywords: Postpartum

contraception.

DOI: $10.20956 / n m s j . v 3 i 1.5772$

\begin{abstract}
Introduction: Postpartum contraception is defined as the utilization of contraceptives within 42 days following labor to prevent close interval of pregnancy. After a live birth, the WHO recommends an interval of at least 24 months before attempting the next pregnancy in order to reduce the risk of adverse maternal, perinatal, and infant outcomes. Several factors influence maternal utilization of contraception after giving birth. Aim of the study is to recognize factors influencing contraception utilization during the postpartum period in Mother and Child Hospital Siti Fatimah Makassar.

Methods: The study employed an observational-analytic, cross sectional method. Seventy respondents were obtained with consecutive sampling. Chi square tests were used to determine linkage value.

Results: The result showed that factors affecting contraception utilization in postpartum period at the Siti Fatimah Mother and Child Hospital Makassar include knowledge about contraception ( $\mathrm{p}$ value $0.000, \mathrm{OR}=24.5(2.995-$ $200.437)$ ), number of children ( $\mathrm{p}$ value $0.004, \mathrm{OR}=4.182(1.541-11.347)$ ), education ( $\mathrm{p}$ value $0.002, \mathrm{OR}=4.915(1.770-13.646)$ ), and husband encouragement ( $p$ value $0,000 \quad, O R=6,240 \quad(2,211-17,608)$ ). The most significant variable was knowledge about contraception.

Conclusion: Factors influencing contraception utilization during the postpartum period include knowledge about contraception, number of children, education, and husband encouragement, with the most significant being knowledge of contraception.
\end{abstract}

\section{INTRODUCTION}

As a developing country, Indonesia's population size remains a major problem. ${ }^{1}$ According to Badan Pusat Statistik (BPS), Indonesia's population in the year 2010 reached 237.6 million. ${ }^{2}$ Hence, control of population growth is required, with family planning being one feasible method. Family planning programs aim to prevent unintended pregnancies, allow people to determine the number and spacing of their children, prevents transmission of sexualtransmitted disease, and reduce abortion rates. ${ }^{3}$

Postpartum contraception is defined as the utilization of contraception within 42 days after giving birth to prevent close pregnancies. ${ }^{3}$ After a live birth, WHO recommends an interval of at least 24 months before attempting another pregnancy, in order to reduce the risk of adverse maternal, perinatal, and infant outcomes. Several studies have shown that short interpregnancy intervals (interval between the delivery date of 
the preceding live birth and the conception date of the index pregnancy) are associated with higher fetal and child death rate.

Several contraception methods in the country's family planning program include oral contraceptive pills, contraceptive injection, implant, intrauterine device (IUD), condom, and sterilization. ${ }^{4}$ In postpartum care, all postnatal women and their husband should be offered counseling regarding contraception by a clinician, so that they can make an informed decision on contraception. Several factors influencing maternal motivation in utilizing postpartum contraception include the preferred number of children, baseline knowledge about fertility at the postpartum period, intention, and awareness to use and implement postpartum contraceptive methods. ${ }^{5}$

Nurbaiti in 2013 found that there were three factors affecting contraceptive utilization including education, knowledge, and husband encouragement. ${ }^{6}$ Additionally, Sunarsih, et al indicated that utilization of contraceptives was associated with age, in which utilization was lower in productive women aged 20-29 years than those aged $30-35$ years. $^{7}$ In a study by Ayu (2016) in Bandar Lampung, a correlation was found between contraceptive utilization and number of children. A study by Jyotsna et al showed that factors influencing contraceptive utilization in postnatal women were education,

\section{RESULTS}

Table 1 shows the frequency distribution of respondents based on postpartum contraceptive utilization, knowledge about contraception, age, knowledge, and resources. ${ }^{9}$ These studies have led the authors of this paper to evaluate factors influencing contraceptive utilization in postpartum period at the Siti Fatimah Mother and Child Hospital, Makassar.

\section{METHODS}

This study was conducted at the Siti Fatimah Mother and Child Hospital in Makassar from September to October 2018. The study used observational analytic with cross sectional method. This study aimed to recognize factors influencing contraceptive utilization in Mother and Child Hospital Siti Fatimah Makassar. Population in this study was postpartum women aged 15-49 years in Mother and Child Hospital Siti Fatimah Makassar and agreed to be respondent. Consecutive sampling technique was used to obtained samples with determined minimal total sample by equation. Seventy postpartum women who met the inclusion criteria were enrolled in this study.

Primary data was obtained by questioner, following approval from the Siti Fatimah Mother and Child Hospital. Data processing was done by editing, coding, transferring, and tabulating using a computerized program to obtain descriptive statistic result. Data analyses in this study consisted of univariate and bivariate analyses.

number of children, education, resources, and husband encouragement. 
Table 1. Respondents frequency distribution based on postpartum contraceptive utilization, knowledge about contraception, age, number of children, education, resources, and husband encouragement.

\begin{tabular}{|c|c|c|c|}
\hline No & Variable & Frequency $(\mathbf{N})$ & Percentage $(\%)$ \\
\hline \multirow[t]{3}{*}{1.} & $\begin{array}{l}\text { Postpartum contraceptive } \\
\text { utilization }\end{array}$ & & \\
\hline & Yes & 36 & 51,4 \\
\hline & No & 34 & 48,6 \\
\hline \multirow[t]{3}{*}{2.} & Knowledge about contrace & & \\
\hline & Good & & 786 \\
\hline & Limited & $\begin{array}{l}5 \\
15\end{array}$ & 21,4 \\
\hline \multirow[t]{3}{*}{3.} & Age & & \\
\hline & $20-40$ years & 62 & 88,5 \\
\hline & $<20$ and $>40$ years & 8 & 11,5 \\
\hline \multirow[t]{3}{*}{4.} & Number of children & & \\
\hline & $>2$ & 35 & 50 \\
\hline & $<2$ & 35 & 50 \\
\hline \multirow[t]{3}{*}{5.} & Education & & \\
\hline & $>9$ years & 32 & 45,7 \\
\hline & $<9$ years & 38 & 54,3 \\
\hline \multirow[t]{3}{*}{6.} & Resources & & \\
\hline & Clinician & 35 & 50 \\
\hline & Media and family & 35 & 50 \\
\hline \multirow[t]{3}{*}{7.} & Husband encouragement & & \\
\hline & Yes & 36 & 51,4 \\
\hline & No & 34 & 48,6 \\
\hline
\end{tabular}

Table 1 shows that 36 respondents $(51.4 \%)$ utilized contraceptives during the postpartum period. Based on knowledge of contraception, 55 respondents $(78.6 \%)$ had good knowledge about postpartum contraceptive utilization. Based on age, 62 respondents $(88.5 \%)$ using postpartum contraceptive were within the age group 20-40 years. Based on the number of children, both groups with less than 2 children and more than 2 children had similar number of respondents, 35 $(50 \%)$ respectively. Based on educational level, most respondents were with education $<9$ years, 38 respondents $(54.3 \%)$. Based on resources, an equal amount of respondents have received information from clinicians and from media or family. Based on husband encouragement, 36 $(51.4 \%)$ respondents were supported by their husband to use contraceptives. 
Table 2. Distribution of variables influencing contraceptive utilization in postpartum period including knowledge of contraception, age, number of children, education, resources, and husband encouragement.

\begin{tabular}{|c|c|c|c|c|c|c|c|}
\hline \multirow{3}{*}{ No } & \multirow{3}{*}{ Variable } & \multicolumn{4}{|c|}{$\begin{array}{c}\text { Contraceptive Utilization in } \\
\text { Postpartum Period }\end{array}$} & \multirow{3}{*}{$P$ value } & \multirow{3}{*}{ OR 95\%CI } \\
\hline & & \multicolumn{2}{|c|}{ Yes } & \multicolumn{2}{|c|}{ No } & & \\
\hline & & $\mathbf{N}$ & $\%$ & $\mathbf{N}$ & $\%$ & & \\
\hline \multirow[t]{3}{*}{1.} & $\begin{array}{l}\text { Knowledge } \\
\text { about } \\
\text { contraception }\end{array}$ & & & & & & \\
\hline & Well & 35 & 50 & 20 & 28,6 & \multirow[t]{2}{*}{0,000} & \multirow{2}{*}{$\begin{array}{c}24,5(2,995- \\
200,437)\end{array}$} \\
\hline & Limited & 1 & 1,43 & 14 & 20 & & \\
\hline \multirow[t]{3}{*}{2.} & Age & & & & & \multirow{3}{*}{0,402} & \multirow{3}{*}{$\begin{array}{l}1,897(0,417- \\
8,635)\end{array}$} \\
\hline & $20-40$ years & 33 & 47,2 & 29 & 41,4 & & \\
\hline & $\begin{array}{l}<20 \text { and }>40 \\
\text { years }\end{array}$ & 3 & 4,3 & 5 & 7,1 & & \\
\hline \multirow[t]{3}{*}{3.} & $\begin{array}{l}\text { Number of } \\
\text { children }\end{array}$ & & & & & & \\
\hline & $>2$ & 24 & 34,2 & 11 & 15,7 & \multirow[t]{2}{*}{0,004} & \multirow{2}{*}{$\begin{array}{l}4,182(1,541- \\
11,347)\end{array}$} \\
\hline & $<2$ & 12 & 17,1 & 23 & 32,8 & & \\
\hline \multirow[t]{3}{*}{4.} & Education & & & & & \multirow{3}{*}{0,002} & \\
\hline & $>9$ years & 23 & 32,8 & 9 & 12,9 & & \multirow{2}{*}{$\begin{array}{c}4,915(1,770- \\
13,646)\end{array}$} \\
\hline & $<9$ years & 13 & 18,6 & 25 & 35,8 & & \\
\hline \multirow[t]{3}{*}{5.} & Resources & & & & & \multirow{3}{*}{0,632} & \multirow{3}{*}{$\begin{array}{c}0,795(0,311- \\
2,034)\end{array}$} \\
\hline & Clinician & 17 & 24,3 & 18 & 25,7 & & \\
\hline & $\begin{array}{l}\text { Media and } \\
\text { family }\end{array}$ & 19 & 27,1 & 16 & 22,9 & & \\
\hline \multirow[t]{3}{*}{6.} & $\begin{array}{l}\text { Husband } \\
\text { encouragement }\end{array}$ & & & & & \multirow{3}{*}{0,000} & \multirow{3}{*}{$\begin{array}{c}6,240(2,211- \\
17,608)\end{array}$} \\
\hline & Yes & 26 & 37,14 & 10 & 14,29 & & \\
\hline & No & 10 & 14,29 & 24 & 34,29 & & \\
\hline
\end{tabular}

The results indicated that there was a significant correlation between knowledge ( $p$ value $=$ 0.000 ), number of children ( $\mathrm{p}$ value $=0.004)$, education $(\mathrm{p}$ value $=0.002)$, husband encouragement ( $p$ value $=0.000)$ with postpartum contraceptive utilization. The results

\section{DISCUSSION}

\section{Effect of Knowledge about Contraception to Postpartum Contraceptive Utilization}

The results show that $35(50 \%)$ respondents with good knowledge about contraception used showed that knowledge had the greatest odd ratio value $(\mathrm{OR}=24.5(2.995-200.437))$. This value was the greatest among other variables, therefore indicating that knowledge was the most influencing factor in postpartum contraceptive utilization.

postpartum contraceptives. In statistic test, $p$ value was 0.000 ( $p$-value $\leq 0.05$ ), it was defined that there was a significant correlation in $5 \%$ of significance between knowledge of contraception with postpartum contraceptive utilization. From risk estimate calculation, OR value of 24.5 $(2.995$ - 200.437) indicated that respondents 
with good knowledge had 24.5 times higher chances of using postpartum contraceptives compared to respondents with limited knowledge.

In study by Endah, there were 29 respondents (64.4\%) with good knowledge about postpartum contraceptives. In conclusion, there was correlation between maternal knowledge of postpartum contraceptives with contraceptive utilization. ${ }^{10}$

\section{Effect of Age to Postpartum Contraceptive Utilization}

The results show that most respondents using postpartum contraceptives were aged 20-40 years, $33(47.2 \%)$ respondents. In statistic test, $p$ value was 0.402 ( $\mathrm{p}$-value $>0.05)$, it was defined that there was no significant correlation in $5 \%$ of significance between age and postpartum contraceptive utilization. From risk estimate calculation, OR of $1.897 \quad(0.417-8.635)$ indicated that respondents aged 20-40 years had 1.897 times chances using postpartum contraceptive compared with respondents aged $<$ 20 years and $>40$ years.

Based on data from Kemenkes (2012), more productive women aged 20-44 years used contraceptives compared to women aged 15-19 years and 45-49 years. It was correlated with this study. In trend of using contraceptive in postnatal women (either live birth or death birth), most respondents in age group 25-29 years and age group 30-34 years used contraceptive, with $86 \%$ and $85 \%$ respectively. While in older age group, it was only $29 \%{ }^{11}$

\section{Effect of the Number of Children to Postpartum Contraceptive Utilization}

Results from this study show that most contraceptive utilization was found in group with number of children $>2$ with 24 respondents $(34.2 \%)$. Statistic test found $p$ value $=0.004(p-$ value $<0.05$ ), it was defined that there was a significant correlation in 5\% of significance between number of children with postpartum contraceptive utilization. From risk estimate calculation, OR of 4.182 (1.541 - 11.347) indicated that respondents with children $>2$ had 4.182 times chances of using postpartum contraceptive compared with respondents with children $<2$. This study was parallel with study by Ayu (2016) in Bandar Lampung suggesting there was correlation between using contraceptive with number of children. ${ }^{8}$

\section{Effect of Education to Postpartum Contraceptive Utilization}

The results from this study show that most contraceptive utilization was found in group with education $>9$ years with $23(32.8 \%)$ respondents. $\mathrm{P}$ value from statistic test was 0.002 (p-value $\leq$ 0.05 ), it means that there was a significant correlation in 5\% significance between educational level with postpartum contraceptive utilization. OR from risk estimate calculation was $4.915(1.770-13.646)$, it means that respondents with education $>9$ years had 4.915 times chances to use postpartum contraceptive compared with respondents with education $<9$ years.

Dewi (2012) in Gayo Luwes District, North Sumatra, suggested that education would influence contraceptive choice and usage which is better to spacing pregnancy. With high level of education, mother able to understand contraceptive benefit and disadvantage. The study was parallel with this study that educational level would influence postpartum contraceptive utilization. ${ }^{2}$

\section{Effect of Resources to Postpartum Contraceptive Utilization}

Results from this study show that most respondents receiving information from clinician used postpartum contraceptive, with 17 respondents $(24.3 \%)$. $\mathrm{P}$ value from statistic test was 0.632 (p-value $>0.05$ ), it means that there was no significant correlation in 5\% significance between resources with postpartum contraceptive utilization. OR from risk estimate calculation was $0.795(0.311$ - 2.034), it means that respondents receiving information from clinician had 0.795 chances to use postpartum contraceptive compared with respondents receiving information from media and family.

Aryanti (2014) suggested that information from contraception worker related to contraceptive choice since some acceptor felt hesitant to use contraceptive. Contraception worker plays an important role to give information, counseling, and explanation about contraceptive. They are asked to be communicative and able to explain completely so acceptor can understand about this matter. Compared with print and electronic media, information from contraception worker is 
considered more clearly than message from other media in order to give information about contraception. From this study, $71.4 \%$ mother receiving information from contraception worker used contraceptive. ${ }^{1}$

\section{Effect of Husband Encouragement to Postpartum Contraceptive Utilization}

Results from this study show that most postpartum contraceptive utilization was found in group supported by their husband, with 29 (37.14\%) respondents. $\mathrm{P}$ value from statistic test was 0.000 ( $p$-value $\leq 0.05)$, it means that there was a significant correlation between husband encouragement with postpartum contraceptive utilization. OR from risk estimate calculation was 6.240 (2.211 - 17.608), it means that respondent supported by their husband had 6.240 times chances to use postpartum contraceptive compared with respondents not supported by their husband. Other studies also suggested that most respondents had more supports. In deciding using contraceptive, husband encouragements include finding information, choosing contraceptive, accompanying to health center, and financing contraceptive application. The more support from husband, the more convenient contraceptive choosing with wife and husband. In contrast, less support from husband leads to husband dissatisfaction regarding contraceptive utilization. ${ }^{13}$

\section{CONCLUSION}

There was a significant correlation between knowledge ( $\mathrm{p}$ value $=0.000)$, number of children $(p$ value $=0.004)$, education $(p$ value $=0.002)$, and husband encouragement $(\mathrm{p}$ value $=0.000)$ with postpartum contraceptive utilization. There was no significant correlation between age and resources with postpartum contraceptive utilization. Results from this study show that knowledge had the greatest odd ratio value, meaning that knowledge was the most influencing factor in postpartum contraceptive utilization. Further study regarding factors influencing contraceptive usage in postpartum period is needed with larger coverage.

\section{REFERENCES}

1. Kholifah., Novianti, R.I. Sikap Ibu Nifas Dalam Keikutsertaan KB di Wilayah Kerja Puskesmas Tambakrejo Kecamatan Jombang Kabupaten Jombang. 2013.

2. Dewi, Soi Ropika. Determinan Pemakaian Alat Kontrasepsi Pada Wanita Pus Di Wilayah Kerja Puskesmas Kota Blangkejeren Kabupaten Gayo Lues. Tesis. Fakultas Kesehatan Masyarakat. Universita Sumatera Utara. 2012.

3. Stephen, S.J., Aryani, P. Gambaran Perilaku Pemakaian Kontrasepsi Pasca Persalinan Pada Wanita Usia Subur di Desa Gelgel, Klungkung-Bali. Directory of Open Access Journals. 2017; 8(2), 144-146.

4. Nigussie, A.T., Girma, D., Tura, G. Postpartum Family Planning Utilization and Associated Factors among Women who Gave Birth in the Past 12 Months, Kebribeyeh Town, Somali Region, Eastern Ethiopia. Journal of Women's Heath Care.2016; 5(6).

5. Noriani, N.K., Teja, A.Y.R., Ariyantini, P.S. Gambaran Penggunaan KB IUD Pada Ibu Pasca Melahirkan. JRKN.2017; 01(01).

6. Nurbaiti. Faktor-Faktor Yang Mempengaruhi Penggunaan Alat Kontrasepsi Intra Uterine Device (IUD) di Wilayah Kerja Puskesmas Simpang Tiga Kabupaten Pidie Tahun 2013. 2013.

7. Sunarsih., Evrianasari, N., Damayanti, R. Faktor-Faktor Yang Berhubungan Dengan Penggunaan Alat Kontrasepsi Pada Wanita Usia Subur (WUS) di Kelurahan Campang Raya Bandar Lampung Tahun 2014. Jurnal Kebidanan. 2015;1(3), 110-115.

8. Wulan, P.A. 2016. Hubungan Tingkat Pengetahuan Pasangan Usia Subur (PUS) Tentang Metode Kontrasepsu Dengan Pemakaian Kontrasepsi di Puskesmas Kartasutra Sukoharjo. Surakarta : Universitas Muhammadiyah Surakarta.

9. Rachmayani, A.N. Faktor-Faktor Yang Berhubungan Dengan Perilaku Penggunaan Kontrasepsi Pada Wanita Usia Subur (WUS) di Provinsi Sumatera Utara [skripsi]. Jakarta: Universitas Islam Negeri Syarif Hidayatullah.2015.

10. Listya, E.P. Hubungan Pengetahuan Ibu Bersalin Tentang KB Pasca Salin Dengan Keikutsertaan Penggunaan KB Pasca Salin Pengguna Jampersal di RSUD Panembahan 
Senopati Bantul Yogyakarta Tahun 2013. 2013.

11. Rachmayani, A.N. Faktor-Faktor Yang Berhubungan Dengan Perilaku Penggunaan Kontrasepsi Pada Wanita Usia Subur (WUS) di Provinsi Sumatera Utara [skripsi]. Jakarta: Universitas Islam Negeri Syarif Hidayatullah.2015.

12. Aryanti, Henry. Faktor-Faktor Yang Berhubungan Dengan Penggunaan
Kontrasepsi Pada Wanita Kawin Usia Dini Di Kecamatan Aikmel Kabupaten Lombok Timur. Tesis. Program Pascasarjana Universitas Udayana. Denpasar. 2014.

13. Susanto, B. 2016 Hubungan Antara Dukungan Suami Terhadap Istri Dengan Keputusan Penggunaan Alat Kontrasepsi di Wilayah Kerja Puskesmas Ngemplak Boyolali [skripsi]. Surakarta: Universitas Muhammadiyah Surakarta. 